\title{
CONTENTS OF VOLUME 18.
}

439. Sensitometry of Photographic Emulsions and a Survey of the Characteristics of Plates and Films of american Manufacture. . Raymond Davis and F. M. Walters, jr.

440. The Spectral Transmissive Properties of Dyes: I. Seven PerMTTTED Food Dyes IN THE VISIBLE, Ultra-VIOLET, AND NEAR INFRARED ................................. G. Gibson, H. J. McNicholas, E. P. T. Tyndall, M. K. Frehafer, and W. E. Mathewson.. 44I. Notes on Standard Wave Lengths Spectographs, and Spectrum TUBES ........................ F. Meggers and Keivin Burns 442. Wave Length MeAsurements in the ARc Spectra of Neodymum and Samartum, .................................. Kiess 443. Measurement of the Color Temperature of the More EFficient ARTIFicial LfGht Sources by the Method of Rotary Dispérsion.... Irwin G. Priest

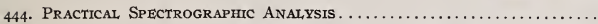

W. F. Meggers, C. C. Kiess, and F. J. Stimson

445. A Piezo-Electric Method for the Instantaneous Measurement of High Pressures. .......................... J. C. Karcher

446. SPECtrophoto-Electrical, Sensitivity of ARgentite $\left(\mathrm{Ag}_{2} \mathrm{~S}\right) \ldots \ldots \ldots \ldots$ W. W. Coblentz

447. Theory, Construction, and Use of the Photometric Integrating Sphere............................ B. Rosa and A. H. Taylor 448. DeCarburization of FERRochromtum by HydRogen.............. Louis Jordan and F. S. Swindells 449. Radio-Frequency Amplifiers .................... D. Lowell 450. An Electron Tube Amplifier Using 6o-Cycle Alternating Current to Supply Power for the Filaments and Plates....P. D. Lowell

45r. Spectrophoto-Electrical, Senstivity of Bournonite and PyrargyRITE......................W.W. Coblentz and J.F. Eckford

452. Structure of Martensitic Carbon Steels and Changes in MicroSTRUCTURE WHICH OCCUR UPON TEMPERING ..................

Henry S. Rawdon and Samuel Epstein

453. Preparation and Properties of Pure Iron Alloys: I. Effects of Carbon and Manganese on the Mechanical, Properties of Pure Iron...................... Robert P. Neville and John R. Cain

454. Action of Charred Paper on the Photographic plate and a Method of Deciphering CharRED Records............... Raymond Davis

455. TABles For the Calculation of the Inductance of Circular CoIls of Rectangular Cross Section ................ Frederick $W$. Grover

456. SPECTROPhoto-Electrical, Sensitivity of Some Halide Salts of Thallium, LEAd, and Silver...W.W. Coblentz and J. F. Eckford

457. Gases in Metals: I. The Determination of Combined Nitrogen in Iron and SteEl, and the Change in Form of Nitrogen by Heat Treatment.................... Louis Jordan and F. E. Swindells 458. Apparatus for the Determination of the Magnetic Properties of SHORT BARS................................. Fischer

Page.

\section{I}

I 2 I

185

201

$22 \mathrm{I}$ 
459. The Structure of Fucose....................... P. Clatk

460. Further Tests of Steliar Radiometers and Some Measurements of Planetary Radiation...................W.W. Coblentz

46r. Spherical Aberration of Thin Lenses.........T. Townsend Smith

462. Various Photo-electrical Investigations.........W. W. Coblentz

463. Preparation and Properties of Pure Iron Alloys: II. Magnetic Properties of Iron-Carbon Alloys as AfFected by Heat Treat-

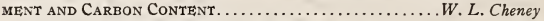

464. Preparation and Properties of Pure Iron Alloys: III. Effect of Manganese on the Structurg of Alloys of the Iron-Carbon System.................... Henry S. Rawdon and Frederick Sillers, $j r$. 465. Composition, Purification, and Certain Constants of Ammonia.... E. C. McKelvy and C. S. Taylor 466. Wave Length Measurements in The ARC Spectra of Gadolinium

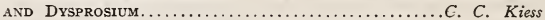

467. Specific Volume of Saturated Ammonia Vapor. 